and preparation but also on getting the personnel to co-operate with one another and to think and act with enthusiasm. Centralisation of administration, that is, control of policies and centralisation of the management of each of the chief functions, did not always in practice go together. Improved management methods had greatly facilitated the centralisation of administrative control, and an economic research department or a statistical department frequently gave specialised assistance. The chief danger of administrative centralisation lies in pushing it to a point at which the initiative of local executives is destroyed and the organisation becomes unrasponsive to variations in local conditions and the demands of local markets.

Administration and management, however, cannot be kept entirely distinct. It is essential to provide that a managerial staff shall be consulted in the formulation of policies, their active consent obtained and their interest aroused, and Dr. Fenelon referred to the advantages of the wise use of committees, and a budgetary system. With regard to the control of particular functions, the extent of centralisation or decentralisation should be determined by the nature of the function, and the relative importance of tech. nical knowledge, personal contacts with customers, etc. Considering types of organisation, Dr. Fenelon referred to methods of co-ordination, through a system of committees, and to the use of staff on the lines advocated by Major Urwick. He suggested that in any industry there was a definite size of organisation beyond which smaller returns on capital and organisation were obtained. Moreover, success or failure was often determined by the willingness or other wise of the chief executives to delegate authority and by the closeness of the attention given to the form of organisation and to the principles of administration.

\title{
Fourth Imperial Entomological Conference
}

$\mathrm{T}$ HE fourth Imperial Entomological Conference, which was summoned on behalf of the Imperial Institute of Entomology and attended by twenty. seven delegates, each representing a different Dominion, Colony or other area of the British Empire, was held in London on September 19-27. The delegates were received by Sir Charles J. Howell Thomas, chairman of the Executive Council, and devoted the remainder of the first morning to the appointment of committees concerned with questions affecting the future policy and activities of the Imperial Institute of Entomology. Afterwards, four mornings or afternoons were devoted to meetings of committees and a final business meeting, and five to public meetings at which papers were read and discussed. Visits were paid to Rothamsted Experimental Station, the Forest Products Research Laboratory, Princes Risborough, the Parasite Labora. tory of the Imperial Institute of Entomology at Farnham Royal, and the Stored Products Research Laboratory, Slough. At Farnham Royal, much interest was taken in a cinematograph film shown by Dr. K. R. S. Morris, illustrating work on the collection in central Europe and Sweden of parasites of pine sawflies (Diprion) for export to Canada.

By the courtesy of the president and council of the Royal Entomological Society of London, the public meetings of the Conference were held in the meeting room of the Society at 41 Queen's Gate; the delegates were also given every facility to use the Society's library.

The papers read and discussed were : locusts and grasshoppers, by Dr. B. P. Uvarov; termites, by Mr. F. P. Jepson; cotton-stainers and their control, by Mr. W. Allan; sheep blowflies, by Dr. G. D. Morison; the biological control of insect pests, by Dr. W. R. Thompson; pests of stored products, by Prof. J. W. Munro; the need for forest entomologists, with special reference to the pinhole borer problem, by Dr. R. C. Fisher; and plant viruses and their insect vectors, by Dr. K. M. Smith.

It is impossible here to give even an outline of the contents of all these papers, but mention may be made of two, selected as typical examples. That by Mr. Jepson attracted great interest, as it was realised that it dealt with problems on the practical aspects of which much work is required and relatively little has been done. Authorities on termites are few, and most of them are primarily interested in the systematic branch of the subject. Mr. Jepson opened by indicating the enormous damage caused by termites to crops, forest trees and all structures in which timber is employed in the tropics and subtropics, and estimated the annual losses as several millions of pounds sterling in the Empire alone. He then devoted the main part of his paper to a very valuable account of the methods found effective in his exporience for the construction of buildings of various types in order to render them proof against invasion by soil-nesting termites, the principle underlying all of them being the insertion between the superstructure and the soil of a barrier of concrete that the insects cannot pass through or round. In his experience (and this was confirmed by speakers in the discussion that followed), Government engineers are usually not inclined to welcome advice on the construction of termite-proof buildings, and great damage to or destruction of valuable buildings constantly results. In addition to excluding subterranean termites, however, it is further necessary, in many countries, to guard against the establishment of drywood termites in the timber of buildings. As these gain admittance in the winged state, the only solution is to use timber that is naturally immune or has been rendered so by artificial treatment. Owing to the contamination of food by the fæcal pellets of these insects, which occurs when they infest roof-timbers, food-safes, etc., the varied protozoan and bacterial fauna of their intestines deserves further study. In Ceylon, it is usually in houses attacked by them that cases of sprue develop, and there is reason for suspecting that the contamination of human food by their solid excrement is in some manner associated with the causation of this disease.

As a result of this paper and the discussion that 
followed, a Committee on Termites was appointed, and the Conference adopted consequent resolutions in which it emphasised the heavy losses caused by termites and the lack of knowledge on them, and recommended the accumulation of data on the financial losses to buildings, agriculture and the forest industry, the identity and habits of the species involved, and methods of control. It also recom. mended that this matter be taken up with the Governments concerned with the view of providing for a thorough investigation of the whole problem.

In contrast to the above, Dr. Uvarov's paper was a report of progress on a subject on which a large amount of co-ordinated study has been carried on for several years. The possibility of preventing outbreaks of locusts is based on the fact that the swarming phase is produced from the solitary one under certain peculiar combinations of external conditions that occur at times in definite and rela. tively restricted areas. Once it is produced, the swarms spread over immense regions, and the invasion develops in spite of all efforts to stem jt. As a result of the extensive international organisa. tion of which the Imperial Institute of Entomology is the centre, records of the movements and breeding of swarms over the infested area of Africa and southwestern Asia are analysed, and from the data thus obtained field investigations are made to locate the centres in which the outbreaks arise, with the view of studying the ecological factors concerned in their commencement and the possibility of preventing it. It has thus been shown that the recent outbreak of the tropical migratory locust, which spread gradually over the greater part of Africa, originated in one or two restricted areas on the Middle Niger, and that the red locust similarly originated in a very few areas in Northern Rhodesia and Tanganyika Territory. Work on the desert locust has not progressed so far, but outbreak centres have been discovered on the coasts of the Sudan and of Baluchistan, and it is almost certain that none exists in the inner deserts of Africa. It will therefore be seen that the international investigations have provided a foundation for a preventive anti-locust policy, by which the outbreak centres can be kept under supervision and incipient outbreaks suppressed.

The discussion that followed afforded evidence that similar outbreak centres are characteristic of the principal injurious grasshoppers of North America and Australia.

\section{Timber in the Box-Making and Coal-Mining Industries*}

$\mathrm{I}^{\mathrm{N}}$ 1931, the Forestry Commissioners appointed an Inter-Departmental Committee to inquire into the possibility of making better use of the timber supplies of Great Britain. An interim report was submitted by this Committee in 1933, and recommended a series of detailed inquiries into the demand for timber for certain specific purposes. A first report dealt with the demand for timber for box and packing-case manufacture in Great Britain, whilst a second, now before us, deals with the demand for timber in coal-mining in England and Wales.

In the first report it was stated that there were two distinct sections of the industry, the box and packing-case makers on one hand, and the shookusing firms who merely assemble the component parts of the boxes already prepared, on the other.

So far as was observed, the timber used for shooks is invariably imported, and there was no evidence that home-grown timber could economically take its place either in character or quality. In the box and packing-case industry, home-grown timber, chiefly spruce and fir, is being extensively used in Scotland, and its suitability for many kinds of boxes is widely admitted in other areas, subject to various provisos. The Scottish firms are using it for mineral-water boxes and beer boxes, for the larger and heavier sizes of fish boxes, for soap boxes, for machinery cases, and cases for shipping rope and generally for any type of box in which light weight and a specially dressed appearance are not essential.

"The fact," says the report, "that, within the limits of the present enquiry, 20 per cent of the timber used by box making firms throughout Scot-

* Forestry Commission. Report on the Demand for Timber for Box and Packing-Case Manufacture in Great Britain. Pp. 47. (London: H.M. Stationery Office, 1934.) $9 d$, net

Forestry Commission. Utilization Series, No. 2 : Report on the Demand for Timber in Coal-Mining in England and Wales. $\mathrm{Pp}$ vi+77. (London: H.M. Stationery Office, 1935.) 18. $3 d$. net. land, and over $40 \%$ of the timber used by those in Aberdeen, is home-grown, is emphatic evidence that home-grown timber could be used more largely than it is in other areas if adequate supplies were available in good condition, and if the cost of transport did not make the price prohibitive." Even in Scotland, a number of criticisms of home-grown timber were made. Perhaps the chief, which certainly restricts its use for the finer and lighter types of packing-cases, is the question of the excessive quantity and size of the knots. The presence or absence of knots in home-grown or any other timber is purely a question of good sylviculture, which, with properly grown and tended plantations, should right itself in the future.

With the interest of the State in afforestation schemes during the past fifteen years, and the creation of State plantations extending to more than 250,000 acres, and with another 100,000 acres of privately owned woods, it is obviously desirable that outlets should be found to absorb the increasing supplies of material which will become available.

In the report on the demand for timber in coalmining, the report shows that the cost of mining timber annually consumed in Great Britain is about $£ 6,000,000$, and represents approximately a cost of $7 d$. on every ton of coal put on the market. Of this quantity, some 21 million loads were imported in 1934. It is said that an increase in the proportion supplied from native sources is possible immediately, and it can be substantially supplemented in the future from plantations at present immature.

The chief need is an effective scheme for marketing the home-grown supplies, and steps towards the attainment of this end have been taken in the formation of a Home-grown Timber Marketing Association under the chairmanship of Lord Clinton. 